\title{
Association between proton pump inhibitors and respiratory infections: A systematic review and meta-analysis of clinical trials
}

\author{
Nabil Sultan MD, Jose Nazareno MD, James Gregor MD
}

\begin{abstract}
N Sultan, J Nazareno, J Gregor. Association between proton pump inhibitors and respiratory infections: A systematic review and meta-analysis of clinical trials. Can J Gastroenterol 2008; 22(9):761-766.
\end{abstract}

BACKGROUND: Proton pump inhibitors (PPIs) have become the mainstay of treatment for and prevention of many serious gastrointestinal diseases. Laboratory and clinical evidence suggests that the increase in gastric $\mathrm{pH}$ caused by PPIs may be linked to increased bacterial colonization of the stomach and may predispose patients to an increased risk for respiratory infections.

OJECTIVE: To examine the association between PPI treatment and respiratory infections.

METHODS: A literature search was conducted using PubMed, MEDLINE and Cochrane databases of randomized, placebocontrolled trials evaluating the efficacy of PPIs. Studies that listed and quantified the specific adverse events of 'respiratory infection' or 'upper respiratory infection' (or equivalent), and compared their rates between PPIs and placebo were included. The $\chi^{2}$ analysis was used to calculate the significance of association in individual studies and a meta-analysis of the selected studies was performed.

RESULTS: Of 7457 studies initially identified and 70 relevant randomized, controlled trials (RCTs) selected, seven studies met the inclusion criteria. A total of 16 comparisons for $\chi^{2}$ analysis were possible given the multiple dosage arms used in several studies. PPIs included in the studies were esomeprazole, rabeprazole, pantoprazole and omeprazole. More than one-half of the studies showed a trend toward an association between PPI use and respiratory infections, although the majority of the studies failed to show a significant correlation. A single study using high-dose esomeprazole (40 mg) showed a significant association $-4.3 \%$ rate of respiratory infections in the active group compared with $0 \%$ in the placebo group $(\mathrm{P}<0.05)$. Meta-analysis showed a trend toward an association between PPIs and respiratory infections, although it failed to reach significance (OR $1.42,95 \%$ CI 0.86 to $2.35 ; \mathrm{P}=0.17$ ).

CONCLUSION: Although a trend was evident in both a $\chi^{2}$ analysis of individual studies and a meta-analysis, the present review and meta-analysis failed to show a conclusive association between PPIs and respiratory infections. Very few RCTs actively sought out respiratory infections, which excluded the majority of RCTs identified. A well-structured, placebo-controlled prospective study would be needed to determine whether a true association between PPIs and respiratory infections exists.

Key Words: Proton pump inhibitors; Respiratory infections
L'association entre les inhibiteurs de la pompe à protons et les infections respiratoires : Une analyse systématique et une méta-analyse des essais cliniques

HISTORIQUE : Les inhibiteurs de la pompe à protons (IPP) son devenus le pilier du traitement et de la prévention de nombreuses maladies gastro-intestinales graves. D'après des données de laboratoire et des données cliniques probantes, l'augmentation du $\mathrm{pH}$ gastrique attribuable aux IPP pourrait être reliée à une colonisation bactérienne accrue de l'estomac et prédisposer les patients à un plus grand risque d'infections respiratoires.

OBJECTIF : Examiner l'association entre le traitement aux IPP et les infections respiratoires.

MÉTHODOLOGIE : À l'aide des bases de données de PubMed, de MEDLINE et de la bibliothèque Cochrane, les auteurs ont effectué une recherche dans les publications afin de trouver les essais aléatoires et contrôlés contre placebo évaluant l'efficacité des IPP. Ils ont inclus les études qui énuméraient et quantifiaient les effets indésirables précis de « l'infection respiratoire " ou de "l'infection des voies respiratoires supérieures » (ou de l'équivalent) et qui comparaient leur taux entre les IPP et les placebos. L'analyse $\chi^{2}$ a permis de calculer la signification de l'association dans les études individuelles et une méta-analyse d'études sélectionnée. RÉSULTATS : Parmi les 7457 études repérées au départ et les 70 essais aléatoires et contrôlés (EAC) sélectionnés, sept études respectaient les critères d'inclusion. Il a été possible de procéder à un total de $16 \mathrm{com}$ paraisons pour les besoins de l'analyse $\chi^{2}$, en raison des multiples groupes de posologie utilisés dans plusieurs études. L'ésoméprazole, le rabéprazole, le pantoprazole et l'oméprazole étaient les IPP inclus dans les études. Plus de la moitié des études ont révélé une tendance vers une association entre le recours aux IPP et les infections respiratoires, même si la majorité des études ne démontraient pas de corrélation significative en ce sens. Une seule étude faisant appel à de l'ésoméprazole à forte dose $(40 \mathrm{mg})$ a indiqué une association significative, soit un taux d'infections respiratoires de $4,3 \%$ dans le groupe actif par rapport à $0 \%$ dans le groupe prenant un placebo $(\mathrm{P}<0,05)$. La méta-analyse a révélé une tendance vers une association entre les IPP et les infections respiratoires, sans pour autant être significative (RRR 1,42, 95 \% IC 0,86 à 2,35, P=0,17).

CONCLUSION : Même si une tendance était évidente à la fois dans l'analyse $\chi^{2}$ des études individuelles et la méta-analyse, les présentes analyse et méta-analyse n'ont pu démontrer d'association concluante entre les IPP et les infections respiratoires. Très peu d'EAC évaluaient les infections respiratoires, ce qui excluait la majorité des EAC repérés. Il faudrait entreprendre une étude prospective bien structurée contrôlée contre placebo pour déterminer s'il existe une véritable association entre les IPP et les infections respiratoires.

London Health Sciences Centre, Division of Gastroenterology, Department of Medicine, Schulich School of Medicine and Dentistry, London, Ontario

Correspondence: Dr Nabil Sultan, London Health Sciences Centre, 339 Windermere Road, London, Ontario N6A 5A5.

Telephone 519-668-7974, fax 519-668-7974,e-mail nmsultan@uwo.ca

Received for publication February 9, 2008. Accepted May 28, 2008 
$\mathrm{P}$ roton pump inhibitors (PPIs) have become the mainstay of treatment and prophylaxis for gastroesophageal reflux disease (GERD) and peptic ulcer disease (PUD), and are one of the most prescribed classes of medications in North America because of both their excellent efficacy and safety profiles (1-3).

The most commonly reported side effects of PPIs include headache, nausea and diarrhea, which occur only slightly more frequently than with placebo in randomized, controlled trials (RCTs). Long-term safety issues with PPIs have become progressively less discussed in recent years, with no long-term complications reported in up to 11 years of continuous use (4). Initial concerns regarding the possible increased risk for atrophic gastritis in Helicobacter pylori-positive patients receiving PPIs and the potential for cancer risk have been refuted by a clinical trial (4). Dosage reduction of PPIs is not necessary, even in patients with compromised renal or hepatic function; all of this has contributed to the soaring popularity of PPI use in the general population.

While initial investigations into complications of PPI use focused on dysplasia and cancer, there has been growing evidence that PPI use may not be completely free of risk. Recent cohort and case-control studies investigating the risk for Clostridium difficile infection with in-hospital PPI use have shown a positive association, with ORs ranging from 2.4 to $2.7(5,6,7)$. More recent data suggest that the association may even extend into the community setting (8).

Laboratory and clinical evidence suggests that a less acidic gastric $\mathrm{pH}$ may be linked to increased bacterial colonization of the stomach (9). This colonization is thought to be an important source of pathogens that could cause pneumonia by translocating to the lungs via the upper digestive and upper respiratory tracts (10). Until recently, studies looking specifically at clinical outcomes such as ventilator-associated pneumonia in the critical care setting have not been definitive in either demonstrating or entirely refuting a link to acid suppressive drugs (ASDs) $(11,12)$. Although it accounts for 60,000 deaths annually in the United States alone, until recently, virtually no attention has been paid to any association between community-acquired pneumonia (CAP) and ASD use. Over the past few years, European population-based studies (13-15) have suggested that an association may exist.

The objective of the present study was to examine the association between the outpatient use of PPIs and respiratory infections, including CAP.

\section{Study identification}

\section{METHODS}

Relevant articles evaluating the efficacy of PPIs published before August 2007 were identified through PubMed, MEDLINE and Cochrane databases. Individual searches using the key words "proton pump inhibitors", "PPI", "esomeprazole", "rabeprazole", "lansoprazole", "pantoprazole" and "omeprazole" were conducted. Studies identified by this method were used to identify additional citations.

\section{Study selection}

The meta-analysis inclusion criteria included randomized, single- or double-blinded, placebo-controlled studies investigating PPIs in various gastrointestinal diseases. Unblinded studies were excluded. Most studies identified had evaluated the use of PPIs in patients with GERD or PUD. Selected studies were required to have clearly presented the prevalence of the specific adverse events of respiratory infection, upper respiratory infection or pneumonia in both treatment and placebo arms. Studies stating no difference in adverse events without explicit mention of respiratory infections were excluded.

\section{Data extraction}

Data regarding adverse events were required to be given explicitly, including clearly stating the adverse events of respiratory infections and upper respiratory infections (or equivalent), with quantification of both active and placebo arms.

\section{Data analysis}

$\chi^{2}$ analyses evaluating active and placebo arms, as well as their association with respiratory infections, were performed to assess the significance of association. A meta-analysis of outcomes was performed by combining trials using the Mantel-Haenszel method (RevMan 4.2; The Cochrane Collaboration, United Kingdom). Statistical heterogeneity was evaluated and $\mathrm{P}<0.1$ was considered significant. Primary outcomes were summarized.

\section{RESULTS}

The initial key word search identified 7457 studies. The majority were excluded because they were either not RCTs or because the control group did not receive a placebo. Most studies identified evaluated the use of PPIs in patients with GERD or PUD. Only 70 RCTs met the major inclusion criteria. Of these 70 studies, 63 were excluded because it was not possible to isolate the adverse events of respiratory infection, upper respiratory infection or pneumonia for the active group, control group or both.

Seven studies (16-22) met all predefined inclusion criteria. All seven studies were peer-reviewed publications. Three studies used esomeprazole, two used omeprazole, one used pantoprazole and one used rabeprazole. All studies compared PPIs with placebos. They ranged in duration from four weeks to six months. A total of 2586 patients (1943 active treatment, 643 placebo) were included in all of the studies. Table 1 summarizes the characteristics of the trials.

Table 2 summarizes the prevalence of respiratory infections in the included studies. The mean prevalence of respiratory infections in the active treatment groups was $4.2 \%$ (range $0 \%$ to $6.6 \%$ ) and in the placebo groups was $2.9 \%$ (range $0 \%$ to $8 \%$ ).

$\chi^{2}$ analyses (Table 3 ) revealed that the majority of trials showed no statistically significant association between PPIs and respiratory infections, although five of seven studies did demonstrate a greater number of infections in the active treatment arm. Only a single treatment arm in one study showed a significant association; this occurred in the esomeprazole $40 \mathrm{mg}$ arm when tested against placebo in a study by Vakil et al (17), revealing a $\mathrm{P}$-value of 0.05 .

A meta-analysis of included studies (Figure 1) revealed no significant association between PPI use and respiratory infection. A total of 84 respiratory infections (of 1943 subjects) occurred in treatment groups and 22 (of 643 subjects) occurred in placebo groups; $4.3 \%$ and $3.4 \%$, respectively. The total OR for developing a respiratory infection with PPI treatment was found to be 1.42 (95\% CI 0.86 to 2.35). The test for overall effect revealed a $\mathrm{P}$-value of 0.17 (deemed insignificant), and the test for heterogeneity revealed a $\mathrm{P}$-value of 0.51 . 


\section{DISCUSSION}

The present study failed to show a significant association between the use of PPIs and respiratory tract infections over the course of use during which these medications are normally initially prescribed. While statistically insignificant, the absolute incidence of respiratory infections was estimated to be $1.3 \%$ higher in patients receiving PPIs than in those receiving placebo. This would translate into a number needed to harm of approximately 77 , suggesting that even if a true association exists, it may have limited clinical significance, except possibly in the most vulnerable patients.

Only a minority of the 70 trials identified actually tracked respiratory infections such as pneumonia. Another limitation of our study is that most studies used the term 'respiratory infections' without clearly defining the diagnostic criteria used (history, radiological, positive cultures, antibiotic use, etc) for those events and, as a result, there may have been a significant degree of subjectivity related to those outcomes. We could not determine the proportion of viral infections in each study, which would be important given that the hypothesis forwarded is that ASDs may cause bacterial respiratory infections through bacterial translocation. There are no randomized trials of PPIs investigating respiratory infections as an end point and we therefore identified respiratory infections followed in RCTs as adverse events. Reporting bias may have influenced the results because only a minority of studies reported the presence or absence of respiratory infections. Despite these limitations, we were able to pool the results of more than 2000 patients from placebo-controlled trials, the strongest level of evidence available.

Our investigation was stimulated in part by the results of two Dutch studies by Laheij et al $(14,15)$. The first, a retrospective questionnaire (15) of 700 outpatients, suggested that ASD users were 2.3 times more likely to have had symptoms of a respiratory infection in the month preceding assessment. In the second, a large cohort of nearly one million patients was studied (14). In this study, the retrospective cohort analysis revealed that ASD users were nearly 4.5 times more likely to develop pneumonia than non-users. A case-control analysis of the same cohort, in an attempt to control for confounders, revealed an adjusted OR of 1.89 for PPIs and 1.63 for histamine-2 receptor antagonists; both values were statistically significant. The authors estimated an attributable risk of one extra case of pneumonia for every 100 years of PPI use.

In the present systematic review and meta-anlaysis, we have not been able to demonstrate a causal relationship between PPIs and pneumonia. However, the link is, without question, plausible. There is an impressive volume of literature supporting several facets of a possible physiological connection. It is clear that ASDs, and especially PPIs, are effective in raising gastric $\mathrm{pH}(23-30)$. Both basic science and clinical data show that higher gastric $\mathrm{pH}$ is associated with gastric bacterial colonization (30-32) and critical care studies have demonstrated an association between ASDs and increased bacterial colonization (25,27-30,33-37). Studies have gone on to show that ASDs are associated with increased translocation of gastric pathogens and secondary respiratory colonization (25,29. $30,32,38-40)$. Furthermore, several studies have shown evidence that specific pathogens causing pneumonia in the critical care setting were of gastric origin $(28,32,33,41)$.

The association is also not without precedence. There has been considerable evidence of an association between
TABLE 1

Studies meeting inclusion criteria for the present study

\begin{tabular}{|c|c|c|c|}
\hline Study & Study arms & $\begin{array}{l}\text { Duration } \\
\text { of study }\end{array}$ & $\begin{array}{l}\text { Total patients, } n \\
\text { (active, placebo) }\end{array}$ \\
\hline $\begin{array}{l}\text { Talley } \\
\text { et al (16) }\end{array}$ & $\begin{array}{l}\text { Esomeprazole } 20 \mathrm{mg} \\
\text { (on demand: mean } \\
7.8 \mathrm{mg} / \text { day) } \\
\text { Placebo }\end{array}$ & 6 months & $342(170,172)$ \\
\hline $\begin{array}{l}\text { Vakil } \\
\text { et al (17) }\end{array}$ & $\begin{array}{l}\text { Esomeprazole } 40 \mathrm{mg} \\
\text { Esomeprazole } 20 \mathrm{mg} \\
\text { Esomeprazole } 10 \mathrm{mg} \\
\text { Placebo }\end{array}$ & 6 months* & $373(281,92)$ \\
\hline $\begin{array}{l}\text { Miner } \\
\text { et al (18) }\end{array}$ & $\begin{array}{l}\text { Rabeprazole } 20 \mathrm{mg} \\
\text { Rabeprazole } 10 \mathrm{mg} \\
\text { Placebo }\end{array}$ & 4 weeks & $203(133,70)$ \\
\hline $\begin{array}{l}\text { Johnson } \\
\text { et al (19) }\end{array}$ & $\begin{array}{l}\text { Esomeprazole } 40 \mathrm{mg} \\
\text { Esomeprazole } 20 \mathrm{mg} \\
\text { Esomeprazole } 10 \mathrm{mg} \\
\text { Placebo }\end{array}$ & 6 months* & $315(238,77)$ \\
\hline $\begin{array}{l}\text { Richter and } \\
\text { Bochenek } \\
(20)\end{array}$ & $\begin{array}{l}\text { Pantoprazole } 40 \mathrm{mg} \\
\text { Pantoprazole } 20 \mathrm{mg} \\
\text { Pantoprazole } 10 \mathrm{mg} \\
\text { Placebo }\end{array}$ & 8 weeks & $603(521,82)$ \\
\hline $\begin{array}{r}\text { Valenzuela } \\
\text { et al (21) }\end{array}$ & $\begin{array}{l}\text { Omeprazole } 40 \mathrm{mg} \\
\text { Omeprazole } 20 \mathrm{mg} \\
\text { Placebo }\end{array}$ & 8 weeks & $520(416,104)$ \\
\hline $\begin{array}{l}\text { Sontag } \\
\text { et al (22) }\end{array}$ & $\begin{array}{l}\text { Omeprazole } 40 \mathrm{mg} \\
\text { Omeprazole } 20 \mathrm{mg} \\
\text { Placebo }\end{array}$ & 8 weeks & $230(184,46)$ \\
\hline Total patients & & & $2586(1943,643)$ \\
\hline
\end{tabular}

${ }^{*}$ Adverse events reported only at one month

histamine-2 receptor antagonists, the most studied form of ASDs in the critical care setting, and ventilator-associated pneumonia $(25-26,28,33)$. Several studies have also shown nonsignificant trends supporting the association $(11,27,29,41)$. The evidence, however, has been mixed, with other studies failing to show any association (34,42-49). Meta-analyses of trials testing ASDs versus sucralfate have supported a possible association, with some showing a significant association between ASDs and pneumonia (50-53), and others showing a nonstatistically significant trend $(11,53-55)$. In these and other studies, the use of ASDs was associated with late, as opposed to early, pneumonia $(33,41)$, possibly accounting for the time required for gastric colonization, translocation and infection (56).

With respect to dose-response, the results of Laheij et al (14) showed that "more than one defined daily dose (DDD)" of PPI has a significantly higher OR for pneumonia than "less than one DDD" (OR 2.63 versus 1.21, respectively). While our study could not provide any conclusive evidence for a doseresponse relationship, one study (17) did find a statistically significant association between PPIs and respiratory infections in $\chi^{2}$ testing, using higher dose esomeprazole $(40 \mathrm{mg}$ versus $10 \mathrm{mg}$ or $20 \mathrm{mg}$ ). However, other trials comparing different doses of PPI failed to show any association across all doses.

Although diseases such as nonvariceal upper gastrointestinal bleeding have a significant case fatality rate of approximately $5 \%$ (57), the case fatality rate of CAP is not insignificant. Of the one million CAP patients requiring hospitalization in the United States annually (58), 2\% to 21\% will 
TABLE 2

Prevalence of respiratory infections in included studies

\begin{tabular}{|c|c|c|c|c|c|c|}
\hline \multirow[b]{2}{*}{ Study } & \multirow[b]{2}{*}{ Adverse event quoted } & \multicolumn{4}{|c|}{ Prevalence of adverse event, \% (absolute number) } & \multirow[b]{2}{*}{ Placebo } \\
\hline & & Active group $\mathrm{A}$ & $\begin{array}{l}\text { Active group B } \\
\text { (if present) }\end{array}$ & $\begin{array}{l}\text { Active group C } \\
\text { (if present) }\end{array}$ & $\begin{array}{l}\text { Total prevalance } \\
\text { (in sum of all } \\
\text { active patients) }\end{array}$ & \\
\hline Vakil et al (17) & Respiratory infection & $4.3(4$ of 92$)$ & $4.1(4$ of 98$)$ & $3.3(3$ of 91$)$ & $3.9(11$ of 281$)$ & $0(0$ of 92$)$ \\
\hline Miner et al (18) & Upper respiratory infection & $0(0$ of 68$)$ & $3.1(2$ of 65$)$ & NA & $1.5(2$ of 133$)$ & $0(0$ of 70$)$ \\
\hline Valenzuela et al (21) & Upper respiratory infection & $3.3(7$ of 214$)$ & $5.0(10$ of 202$)$ & NA & $5.1(17$ of 416$)$ & $1.9(2$ of 104$)$ \\
\hline Sontag et al (22) & Upper respiratory infection & $2.2(2$ of 91$)$ & $2.2(2$ of 93$)$ & NA & $2.2(4$ of 184$)$ & $4.3(2$ of 46$)$ \\
\hline
\end{tabular}

NA Not applicable

TABLE 3

$\chi^{2}$ testing for an association between proton pump inhibitor use and respiratory infections in individual studies, and their treatment arms

\begin{tabular}{|c|c|c|c|c|}
\hline Study & $\begin{array}{l}\text { Active } \\
\text { intervention }\end{array}$ & $\begin{array}{c}\text { Prevalance of respiratory } \\
\text { infection in active intervention }\end{array}$ & $\begin{array}{l}\text { Prevalence of respiratory } \\
\text { infection in placebo }\end{array}$ & $\mathbf{P}$ \\
\hline Talley et al (16) & Esomeprazole $20 \mathrm{mg}$ & 11 of 170 & 13 of 172 & $<1.0$ \\
\hline \multirow[t]{3}{*}{ Vakil et al (17) } & Esomeprazole $40 \mathrm{mg}$ & 4 of 92 & 0 of 94 & $<0.05$ \\
\hline & Esomeprazole $20 \mathrm{mg}$ & 4 of 98 & 0 of 94 & $<0.1$ \\
\hline & Esomeprazole $10 \mathrm{mg}$ & 3 of 91 & 0 of 94 & $<0.1$ \\
\hline \multirow[t]{2}{*}{ Miner et al (18) } & Rabeprazole 20 mg & 0 of 68 & 0 of 70 & Not applicable \\
\hline & Rabeprazole $10 \mathrm{mg}$ & 2 of 65 & 0 of 70 & $<0.2$ \\
\hline \multirow[t]{3}{*}{ Johnson et al (19) } & Esomeprazole $40 \mathrm{mg}$ & 5 of 81 & 2 of 77 & $<1.0$ \\
\hline & Esomeprazole $20 \mathrm{mg}$ & 4 of 81 & 2 of 77 & $<1.0$ \\
\hline & Esomeprazole $10 \mathrm{mg}$ & 5 of 76 & 2 of 77 & $<1.0$ \\
\hline \multirow[t]{3}{*}{ Richter and Bochenek (20) } & Pantoprazole 40 mg & 10 of 173 & 3 of 82 & $<1.0$ \\
\hline & Pantoprazole 20 mg & 6 of 174 & 3 of 82 & $<1.0$ \\
\hline & Pantoprazole $10 \mathrm{mg}$ & 9 of 174 & 3 of 82 & $<1.0$ \\
\hline \multirow[t]{2}{*}{ Valenzuela et al (21) } & Omeprazole 40 mg & 7 of 214 & 2 of 104 & $<1.0$ \\
\hline & Omeprazole 20 mg & 10 of 202 & 2 of 104 & $<0.2$ \\
\hline \multirow[t]{2}{*}{ Sontag et al (22) } & Omeprazole 40 mg & 2 of 91 & 2 of 46 & $<1.0$ \\
\hline & Omeprazole 20 mg & 2 of 93 & 2 of 46 & $<1.0$ \\
\hline
\end{tabular}

Review: $\quad$ PPI use and respiratory intecfions

Comparison: $01 \mathrm{PPI}$ use and incidence of respiratory infections

Outcome: 01 incidence of respiratory infections

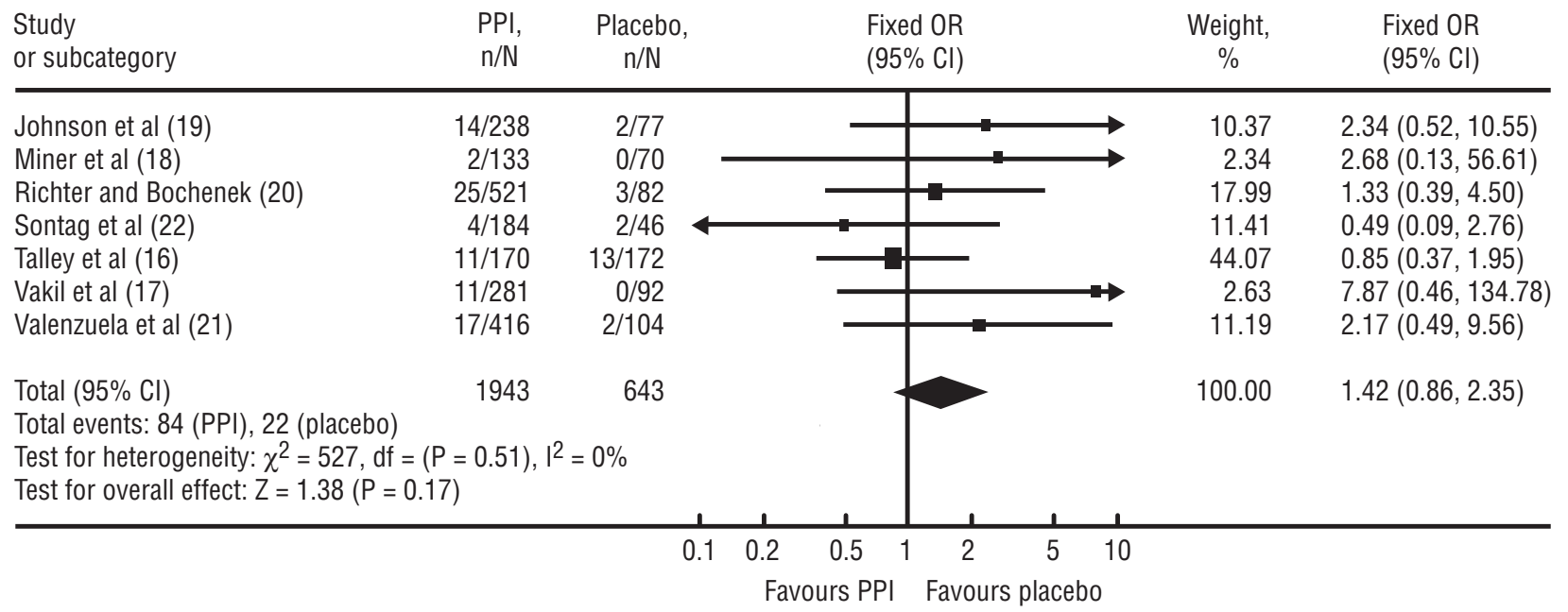

Figure 1) Results of a meta-analysis testing the association between proton pump inhibitors (PPIs) and respiratory infections. $d f$ Degrees of freedom 
succumb to their illness; this figure rises to 50\% among patients with severe disease (59). If PPIs do cause some cases of CAP, the risk-benefit ratio of chronic PPI administration clearly needs to be taken into account, particularly when administered to asymptomatic individuals for prophylactic indications such as the prevention of nonsteroidal antiinflammatory-induced ulcers. This concern is highlighted by recent evidence that up to $60 \%$ of primary care PPI prescriptions may not be fulfilling established PPI indications (60), and by other data showing the explosive growth of the PPI market, with a British study (61) showing a growth of $456 \%$ in PPI prescriptions from 1992 to 1997.

The development and use of PPIs has led to a revolution in the management and prophylaxis of some of the most serious and debilitating diseases of the upper gastrointestinal tract over the past two decades. While it is not always possible to perform placebo-controlled trials to answer every clinical question, particularly those pertaining to relatively rare adverse events, the indications for the use of PPIs are sufficiently common that such a trial is likely feasible. Such a study would aid physicians and their patients in making informed decisions regarding the chronic administration of ASD therapy.

\section{REFERENCES}

1. Chiba N, De Gara CJ, Wilkinson JM, Hunt RH. Speed of healing and symptom relief in grade II to IV gastroesophageal reflux disease: A meta-analysis. Gastroenterology 1997;112:1798-810.

2. Valenzuela JE, Berlin RG, Snape WJ, et al. US experience with omeprazole in duodenal ulcer. Multicenter double-blind comparative study with ranitidine. The Omeprazole DU Comparative Study Group. Dig Dis Sci 1991;36:761-8.

3. Laine L, Ahnen D, McClain C, Solcia E, Walsh JH. Review article: Potential gastrointestinal effects of long-term acid suppression with proton pump inhibitors. Aliment Pharmacol Ther 2000;14:651-68.

4. Klinkenberg-Knol EC, Nelis F, Dent J, et al. Long-term omeprazole treatment in resistant gastroesophageal reflux disease: Efficacy, safety, and influence on gastric mucosa. Gastroenterology 2000;118:661-9.

5. Cunningham R, Dale B, Undy B, Gaunt N. Proton pump inhibitors as a risk factor for Clostridium difficile diarrhoea. J Hosp Infect 2003;54:243-5.

6. Dial S, Alrasadi K, Manoukian C, Huang A, Menzies D. Risk of Clostridium difficile diarrhea among hospital inpatients prescribed proton pump inhibitors: Cohort and case-control studies. CMAJ 2004;171:33-8.

7. Muto CA, Pokrywka M, Shutt K, et al. A large outbreak of Clostridium difficile-associated disease with an unexpected proportion of deaths and colectomies at a teaching hospital following increased fluoroquinolone use. Infect Control Hosp Epidemiol 2005;26:273-80.

8. Dial S, Delaney JA, Barkun AN, Suissa S. Use of gastric acid-suppressive agents and the risk of community-aquired Clostridium difficile-associated disease. JAMA 2005;294:2989-95.

9. Theisen J, Nehra D, Citron D, et al. Suppression of gastric acid secretion in patients with gastroesophageal reflux disease results in gastric bacterial overgrowth and deconjugation of bile acids. Gastrointest Surg 2000;4:50-4.

10. Craven DE, Steger KA. Epidemiology of nosocomial pneumonia: New perspectives on an old disease. Chest 1995;108(2 Suppl):1S-16S

11. Cook D, Guyatt G, Marshall J, et al. A comparison of sucralfate and ranitidine for the prevention of upper gastrointestinal bleeding in patients requiring mechanical ventilation. Canadian Critical Care Trials Group. N Engl J Med 1998;338:791-7.

12. Mallow S, Rebuck JA, Osler T, Ahern J, Healey MA, Rogers FB. Do proton pump inhibitors increase the incidence of nosocomial pneumonia and related infectious complications when compared with histamine-2 receptor antagonists in critically ill trauma patients? Curr Surg 2004;61:452-8.
13. Gulmez SE, Holm A, Frederiksen H, Jensen TG, Pedersen C, Hallas J. Use of proton pump inhibitors and the risk of communityacquired pneumonia: A population-based case-control study. Arch Int Med 2007;167:950-5.

14. Laheij RJ, Sturkenboom MC, Hassing RJ, Dieleman J, Stricker BH, Jansen JB. Risk of community-acquired pneumonia and use of gastric acid-suppressive drugs. JAMA 2004;292:1955-60.

15. Laheij RJ, Van Ijzendoorn MC, Janseen MJ, Jansen JB. Gastric acid-suppressive therapy and community-acquired respiratory infections. Aliment Pharmacol Ther 2003;18:847-51.

16. Talley NJ, Lauritsen K, Tunturi-Hihnala $\mathrm{H}$, et al. Esomeprazole $20 \mathrm{mg}$ maintains symptom control in endoscopy-negative gastro-oesophageal reflux disease: A controlled trial of 'on-demand' therapy for 6 months. Aliment Pharmacol Ther 2001; 15:347-54.

17. Vakil NB, Shaker R, Johnson DA, et al. The new proton pump inhibitor esomeprazole is effective as a maintenance therapy in GERD patients with healed erosive oesophagitis: A 6-month, randomized, double-blind, placebo-controlled study of efficacy and safety. Aliment Pharmacol Ther 2001;15:927-35.

18. Miner P Jr, Orr W, Filippone J, Jokubaitis L, Sloan S. Rabeprazole in nonerosive gastroesophageal reflux disease: A randomized placebo-controlled trial. Am J Gastroenterol 2002;97:1332-9.

19. Johnson DA, Benjamin SB, Vakil NB, et al. Esomeprazole once daily for 6 months is effective therapy for maintaining healed erosive esophagitis and for controlling gastroesophageal reflux disease symptoms: A randomized, double-blind, placebo-controlled study of efficacy and safety. Am J Gastroenterol 2001;96:27-34. (Erratum in 2001;96:942).

20. Richter JE, Bochenek W. Oral pantoprazole for erosive esophagitis: A placebo-controlled, randomized clinical trial. Pantoprazole US GERD Study Group. Am J Gastroenterol 2000;95:3071-80.

21. Valenzuela JE, Kogut DG, McCullough AJ, et al. Comparison of once-daily doses of omeprazole ( 40 and $20 \mathrm{mg}$ ) and placebo in the treatment of benign gastric ulcer: A multicenter, randomized, double-blind study. Am J Gastroenterol 1996;91:2516-22.

22. Sontag SJ, Hirschowitz BI, Holt S, et al. Two doses of omeprazole versus placebo in symptomatic erosive esophagitis: The U.S. Multicenter Study. Gastroenterology 1992;102:109-18.

23. Somberg L, Karlstadt R, Gallagher K, et al. Intravenous pantoprazole rapidly achieves $\mathrm{pH}>4.0$ in ICU patients without the development of tolerance. Gastroenterology 2001;120:A838. (Abst)

24. Spechler SJ, Sharma P, Traxler B, Levine D, Falk GW. Gastric and esophageal $\mathrm{pH}$ in patients with Barrett's esophagus treated with three esomeprazole dosages: A randomized, double-blind, crossover trial. Am J Gastroenterol 2006;101:1964-71.

25. Eddleston JM, Vohra A, Scott P, et al. A comparison of the frequency of stress ulceration and secondary pneumonia in sucralfate- or ranitidine-treated intensive care unit patients. Crit Care Med 1991;19:1491-6.

26. Tryba M. Risk of acute stress bleeding and nosocomial pneumonia in ventilated intensive care unit patients: Sucralfate versus antacids. Am J Med 1987;83(3B):117-24.

27. Kappstein I, Schulgen G, Friedrich T, et al. Incidence of pneumonia in mechanically ventilated patients treated with sucralfate or cimetidine as prophylaxis for stress bleeding: Bacterial colonization of the stomach. Am J Med 1991;91(2A):125S-31S.

28. Apte NM, Karnad DR, Medhekar TP, Tilve GH, Morye S, Bhave GG. Gastric colonization and pneumonia in intubated critically ill patients receiving stress ulcer prophylaxis: A randomized, controlled trial. Crit Care Med 1992;20:590-3.

29. Driks MR,Craven DE, Celli BR, et al. Nosocomial pneumonia in intubated patients given sucralfate as compared with antacids or histamine type 2 blockers. The role of gastric colonization. N Engl J Med 1987;317:1376-82.

30. Ephgrave KS, Kleiman-Wexler R, Pfaller M, et al. Effects of sucralfate vs antacids on gastric pathogens: Results of a double-blind clinical trial. Arch Surg 1998;133:251-7.

31. Mehta S, Archer JF, Mills J. pH-dependent bactericidal barrier to gram-negative aerobes: Its relevance to airway colonisation and prophylaxis of acid aspiration and stress ulcer syndromes - study in vitro. Intensive Care Med 1986;12:134-6.

32. Daschner F, Kappstein I, Engels I, et al. Stress ulcer prophylaxis and ventilation pneumonia: Prevention by antibacterial cytoprotective agents? Infect Control Hosp Epidemiol 1988;9:59-65. 
33. Prod'hom G, Leuenberger P, Koerfer J, et al. Nosocomial pneumonia in mechanically ventilated patients receiving antacid, ranitidine, or sucralfate as prophylaxis for stress ulcer. A randomized controlled trial. Ann Intern Med 199415;120:653-62.

34. Mahul P, Auboyer C, Jospe R, et al. Prevention of nosocomial pneumonia in intubated patients: Respective role of mechanical subglottic secretions drainage and stress ulcer prophylaxis. Intensive Care Med 1992;18:20-5.

35. Vincent JL. Prevention of nosocomial bacterial pneumonia Thorax 1999;54:544-9.

36. Donowitz LG, Page MC, Mileur BL, Guenthner SH. Alteration of normal gastric flora in critical care patients receiving antacid and cimetidine therapy. Infect Control 1986;7:23-6.

37. Garvey BM, McCambley JA, Tuxen DV. Effects of gastric alkalization on bacterial colonization in critically ill patients. Crit Care Med 1989;17:211-6.

38. Atherton ST, White DJ. Stomach as source of bacteria colonising respiratory tract during artificial ventilation. Lancet 1978;2:968-9.

39. du Moulin GC, Paterson DG, Hedley-Whyte J, Lisbon A. Aspiration of gastric bacteria in antacid-treated patients: A frequent cause of postoperative colonisation of the airway. Lancet 1982;1:242-5.

40. Ephgrave KS, Kleiman-Wexler R, Pfaller M, Booth B, Werkmeister L, Young S. Postoperative pneumonia: A prospective study of risk factors and morbidity. Surgery 1993;114:815-9; discussion 819-211.

41. Thomason MH, Payseur ES, Hakenewerth AM, et al. Nosocomial pneumonia in ventilated trauma patients during stress ulcer prophylaxis with sucralfate, antacid, and ranitidine. J Trauma 1996;41:503-8.

42. Noseworthy TW, Cook DJ. Nosocomial pneumonia, prophylaxis against gastric erosive disease, and clinically important gastrointestinal bleeding: Where do we stand? Crit Care Med 1993;21:1814-6.

43. Ryan P, Dawson J, Teres D, Celoria G, Navab F. Nosocomial pneumonia during stress ulcer prophylaxis with cimetidine and sucralfate. Arch Surg 1993;128:1353-7.

44. Cioffi WG, McManus AT, Rue LW III, Mason AD, McManus WF, Pruitt BA Jr. Comparison of acid neutralizing and non-acid neutralizing stress ulcer prophylaxis in thermally injured patients. J Trauma 1994;36:544-6.

45. Martin LF, Booth FV, Karlstadt RG, et al. Continuous intravenous cimetidine decreases stress-related upper gastrointestinal hemorrhage without promoting pneumonia. Crit Care Med 1993;21:19-30.

46. Metz CA, Livingston DH, Smith JS, Larson GM, Wilson TH. Impact of multiple risk factors and ranitidine prophylaxis on the development of stress-related upper gastrointestinal bleeding: A prospective, multicenter, double-blind, randomized trial. The Ranitidine Head Injury Study Group. Crit Care Med 1993;21:1844-9.

47. Vincent JL, Bihari DJ, Suter PM, et al. The prevalence of nosocomial infection in intensive care units in Europe. Results of the European
Prevalence of Infection in Intensive Care (EPIC) Study. EPIC International Advisory Committee. JAMA 1995;274:639-44.

48. Bonten MJ, Gaillard CA, van der Geest S, et al. The role of intragastric acidity and stress ulcus prophylaxis on colonization and infection in mechanically ventilated ICU patients. A stratified, randomized, double-blind study of sucralfate versus antacids. Am J Respir Crit Care Med 1995;152:1825-34.

49. Ben-Menachem T, Fogel R, Patel RV, et al. Prophylaxis for stressrelated gastric hemorrhage in the medical intensive care unit. A randomized, controlled, single-blind study. Ann Intern Med 1994;121:568-75.

50. Messori A, Trippoli S, Vaiani M, Gorini M, Corrado A. Bleeding and pneumonia in intensive care patients given ranitidine and sucralfate for prevention of stress ulcer: Meta-analysis of randomised controlled trials. BMJ 2000;321:1103-6.

51. Tryba M, Cook DJ. Gastric alkalinization, pneumonia, and systemic infections: The controversy. Scand J Gastroenterol Suppl 1995;210:53-9.

52. Cook DJ. Stress ulcer prophylaxis: Gastrointestinal bleeding and nosocomial pneumonia. Best evidence synthesis. Scand J Gastroenterol Suppl 1995;210:48-52.

53. Tryba M. Sucralfate versus antacids or $\mathrm{H} 2$-antagonists for stress ulcer prophylaxis: A meta-analysis on efficacy and pneumonia rate. Crit Care Med 1991;19:942-9.

54. Cook DJ, Reeve BK, Guyatt GH, et al. Stress ulcer prophylaxis in critically ill patients. Resolving discordant meta-analyses. JAMA 1996;275:308-14.

55. Cook DJ, Laine LA, Guyatt GH, Raffin TA. Nosocomial pneumonia and the role of gastric $\mathrm{pH}$. A meta-analysis. Chest 1991;100:7-13.

56. George DL, Falk PS, Wunderink RG, et al. Epidemiology of ventilator-acquired pneumonia based on protected bronchoscopic sampling. Am J Respir Crit Care Med 1998;158:1839-47.

57. Barkun A, Sabbah S, Enns R, et al; RUGBE Investigators. The Canadian Registry on Nonvariceal Upper Gastrointestinal Bleeding and Endoscopy (RUGBE): Endoscopic hemostasis and proton pump inhibition are associated with improved outcomes in a real-life setting. Am J Gastroenterol 2004;99:1238-46.

58. Niederman MS, McCombs JS, Unger AN, Kumar A, Popovian R. The cost of treating community-acquired pneumonia. Clin Ther 1998;20:820-37.

59. Marrie TJ. Community-acquired pneumonia: Epidemiology, etiology, treatment. Infect Dis Clin North Am 1998;12:723-40.

60. De Burgos Lunar C, Novo Del Castillo S, Llorente Diaz E, Salinero Fort MA. [Study of prescription-indication of proton pump inhibitors.] Rev Clin Esp 2006;206:266-70.

61. Boath EH, Blenkinsopp A. The rise and rise of proton pump inhibitor drugs: Patients' perspectives. Soc Sci Med 1997;45:1571-9. 


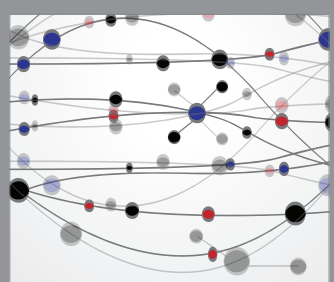

The Scientific World Journal
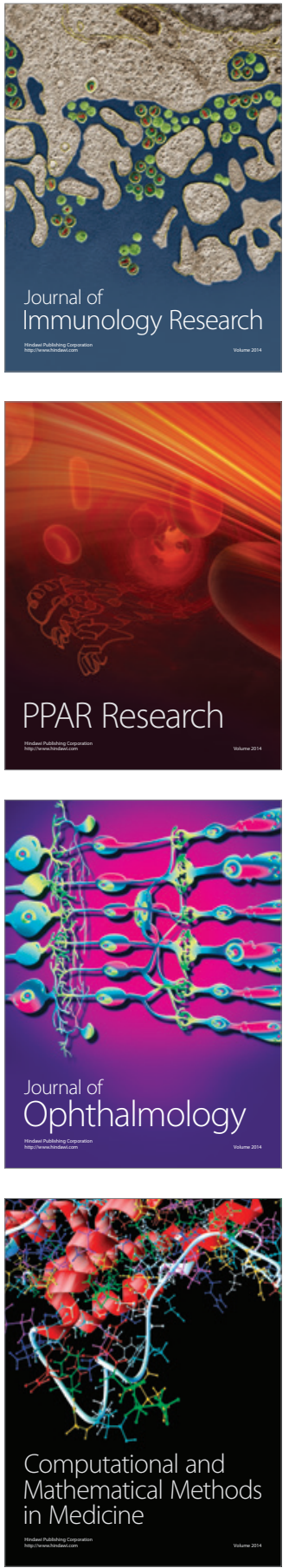

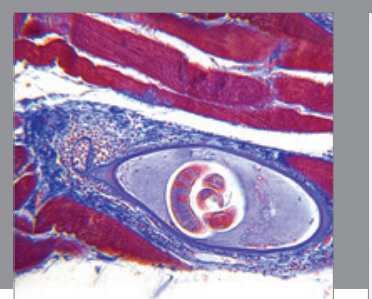

Gastroenterology Research and Practice

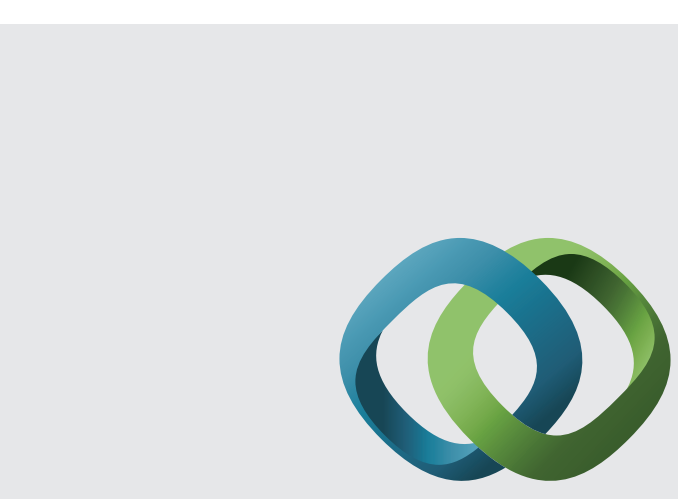

\section{Hindawi}

Submit your manuscripts at

http://www.hindawi.com
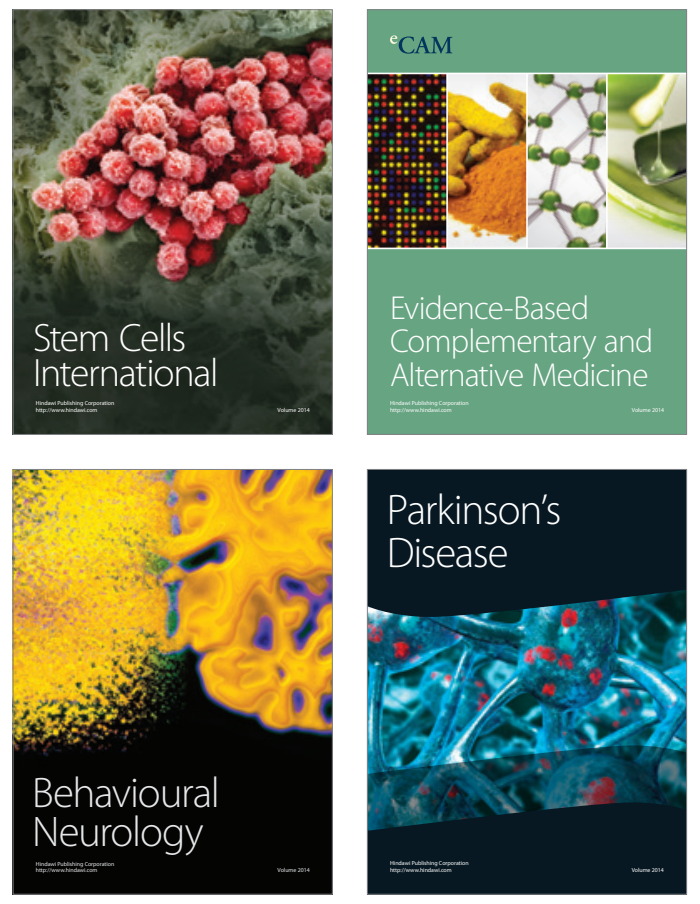
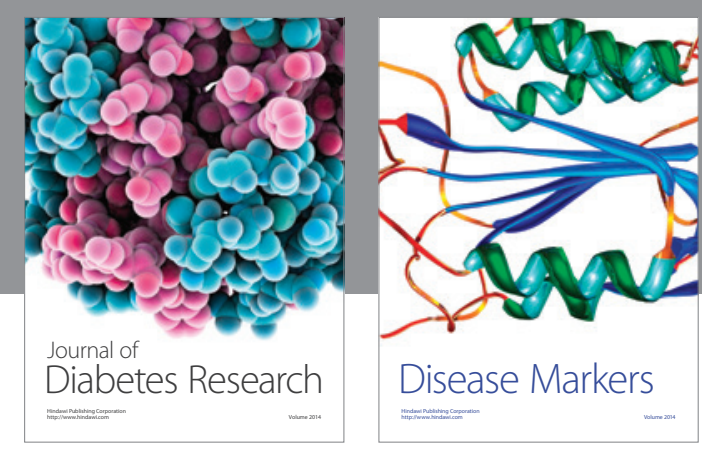

Disease Markers
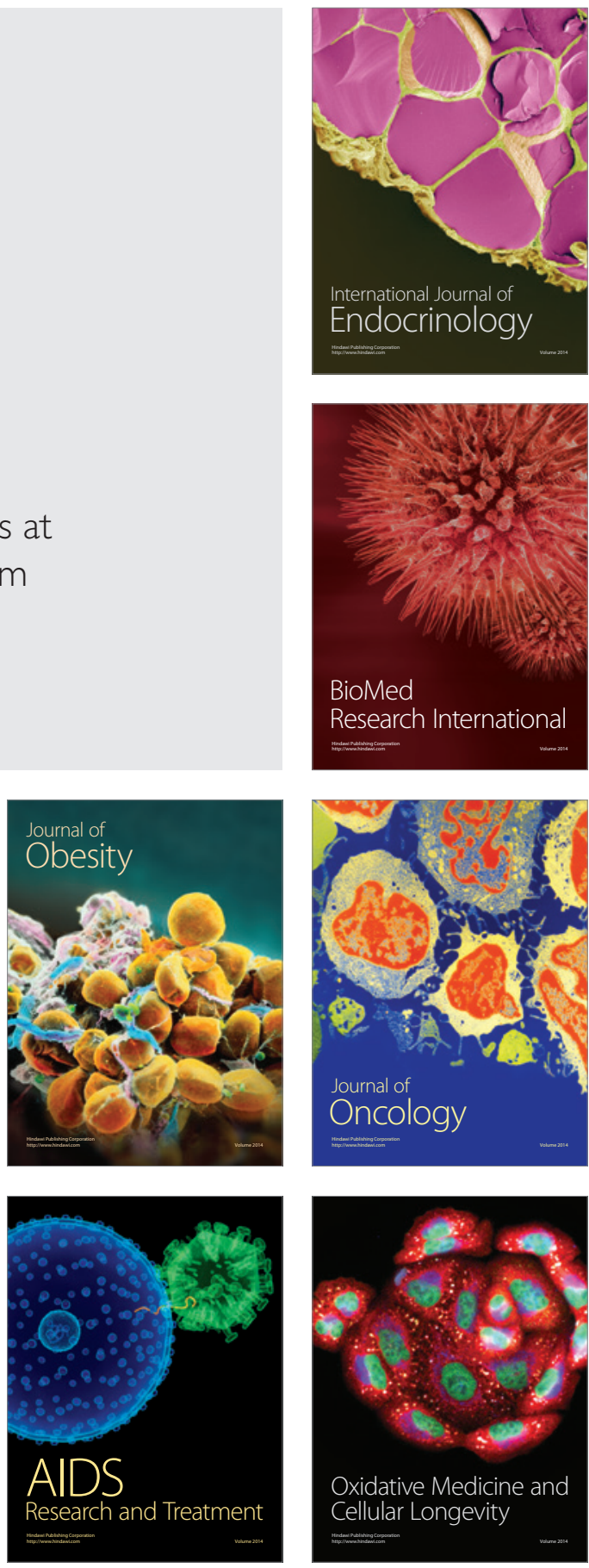